II presente documento viene fornito attraverso il servizio NILDE dalla Biblioteca fornitrice, nel rispetto della vigente normativa sul Diritto d'Autore (Legge n.633 del 22/4/1941 e successive modifiche e integrazioni) e delle clausole contrattuali in essere con il titolare dei diritti di proprietà intellettuale.

La Biblioteca fornitrice garantisce di aver effettuato copia del presente documento assolvendo direttamente ogni e qualsiasi onere correlato alla realizzazione di detta copia.

La Biblioteca richiedente garantisce che il documento richiesto è destinato ad un suo utente, che ne farà uso esclusivamente personale per scopi di studio o di ricerca, ed è tenuta ad informare adeguatamente i propri utenti circa i limiti di utilizzazione dei documenti forniti mediante il servizio NILDE.

La Biblioteca richiedente è tenuta al rispetto della vigente normativa sul Diritto d'Autore e in particolare, ma non solo, a consegnare al richiedente un'unica copia cartacea del presente documento, distruggendo ogni eventuale copia digitale ricevuta.

Biblioteca richiedente: Bioversity International Library

Data richiesta: $\quad 19 / 05 / 201609: 30: 56$

Biblioteca fornitrice: $\quad$ Biblioteca del Polo Papardo. Punto di erogazione 5: Area delle Scienze MM.FF.NN.

Data evasione: 19/05/2016 09:55:21

Titolo rivista/libro: Journal of international development (Online)

Titolo articolo/sezione: What Do We Mean by 'Women's Crops'? Commercialisation, Gender and the Power to Name

Autore/i:

ISSN:

$1099-1328$

DOI:

10.1002/jid.3224

Anno:

2016

Volume:

Fascicolo:

Editore:

Pag. iniziale:

On line first

Pag. finale:

On line first 


\title{
WHAT DO WE MEAN BY 'WOMEN'S CROPS'? COMMERCIALISATION, GENDER AND THE POWER TO NAME
}

\author{
ALASTAIR ORR $^{1 *}$, TAKUJI TSUSAKA ${ }^{2}$, SABINE HOMANN KEE-TUI ${ }^{3}$ and HARRY MSERE ${ }^{2}$ \\ ${ }^{1}$ ICRISAT_Nairobi, Nairobi, Kenya \\ ${ }^{2}$ ICRISAT-Lilongwe, Lilongwe, Malawi \\ ${ }^{3}$ ICRISAT_Bulawayo, Bulawayo, Zimbabwe
}

\begin{abstract}
We explore the relationship between commercialisation and gender for groundnuts in Eastern Province, Zambia, using a mixed methods approach. Women saw themselves as having greater control over groundnuts than other crops, and both sexes saw groundnuts as controlled by women. Propensity Score Matching showed that machine shelling and higher sales did not reduce women's perceived level of control over groundnuts. On the other hand, women welcomed greater male participation in machine shelling because it reduced the drudgery of shelling by hand, and were willing to trade some control in exchange for the male labour required to capture the full benefits from commercialisation. This suggests the need to re-think the narrative of commercalisation and gender as a zero sum game in favour of a cooperative-conflict model where bargaining between women and men can result in higher incomes for them both.
\end{abstract}

Keywords: Gender; Commercialisation; mixed methods; Zambia

\section{INTRODUCTION}

It is widely believed that the commercialisation of food crops disempowers women. Traditional gender roles view women as the providers of food and men as the providers of wage goods. When food crops become commercialised, these gender roles conflict. Typically, men then assert their role as providers as wage goods to gain control of the income from food crops, relegating women to suppliers of labour. The paradigmatic case is irrigated rice in The Gambia, where commercialisation subverted women's rights to land, increased men's control over their labour power and turned female farmers into hired

*Correspondence to: Alastair Orr, ICRISAT—Nairobi, Nairobi, Kenya.

E-mail: a.orr@cgiar.orgc

\footnotetext{
${ }^{1}$ Aside from the references to Carney and Watts $(1990,1991)$ cited in the preceding texts, also refer to the studies
} by Dey $(1981,1982)$ and von Braun and Webb (1989), not to mention Carney $(1988,1992,1998)$. 


\section{A. Orr et al.}

workers (Carney \& Watts, 1990, 1991). The adverse impact of commercialisation on women in The Gambia became a minor cottage industry. ${ }^{1}$ Subsequently, researchers seem to have lost interest in this topic, although work on global value chains supports these earlier conclusions (Dolan, 2001). In short, everything we know about commercialisation points to the dispiriting conclusion that it is bad news for women.

The effect of commercialisation on women is therefore framed as a zero sum game. Commercialisation is evaluated by investigating changes in women's autonomy or their degree of control. Because these categories are finite, one person's loss of autonomy or control is another's gain. There can only be winners and losers. This framing is reflected in language. Commercialisation is portrayed in war-like metaphors as a gender 'conflict' where men and women contest 'terrain', establish 'beach-heads' and turn households into 'battlegrounds' (Carney \& Watts, 1991). Although a quarter of a century old, this narrative, with its powerful mix of Marxism and feminism, exerts a magnetic pull that is hard to resist. It remains the primary frame of reference for thinking about the relationship between gender and commercialisation.

In this paper, we challenge this framing of commercialisation and gender. Based on fieldwork with women groundnut farmers in Zambia, we argue that while some of their attitudes match this narrative, others do not. While defending their power to name groundnuts as a women's crop, the women were also willing to cooperate with men. In particular, the women were prepared to trade some degree of autonomy in exchange for greater male participation in shelling groundnuts. We expected the women to see male involvement in mechanised shelling as a threat. Instead, they saw it as freeing them from drudgery. Moreover, by relieving this labour bottleneck, the women saw male participation in shelling as an opportunity to increase income for the whole household. This suggests that the women did not see the commercialisation of groundnuts as a zero sum game but were willing to bargain and negotiate, welcoming greater male participation while striving to retain operational and financial control.

Our analysis proceeds on two axes. The first axis is the concept of 'women's crops'. Historically, Africa was 'the region of female farming par excellence' (Boserup, 1989), where crops were women's crops by definition. ${ }^{2}$ Today, women's crops are more difficult to define. One helpful distinction is between separate crops, fields and tasks (Cloud, 1985). The concept of separate crops is problematic because despite claims to the contrary, women no longer supply most of the labour for crop production in Sub-Saharan Africa, at least for staple food crops (World Bank, 2015; Enete, Nweke, \& Tollens, 2002). Likewise, in Ghana, no crops are grown exclusively by women, whether by households headed by women, or on fields held by women or on fields from which women kept the income, although some crops are more commonly grown by women (Doss, 2002). Commercialisation blurs this pattern, with women in market-oriented households growing crops that are otherwise grown mostly by men (Carr, 2008). However, women do often have their own fields, and women are still mainly responsible for certain crop management tasks, like weeding. Furthermore, there is a traditional 'gender division of control', whereby the income from particular crops is controlled by men or women (Geisler, 1993).

The second axis of analysis is language. Crops are named as 'women's' or 'men's crops' according to cultural beliefs about gender roles. For example, hybrid maize in Zambia was named a 'man's crop' because its poor taste and storage qualities made it more suitable for

\footnotetext{
${ }^{2}$ Although researchers have challenged Boserup's thesis on several fronts, 'they have not dislodged the fundamental premise that female labour is central to African agriculture'. (Bryceson, 1995, p. 7).
} 


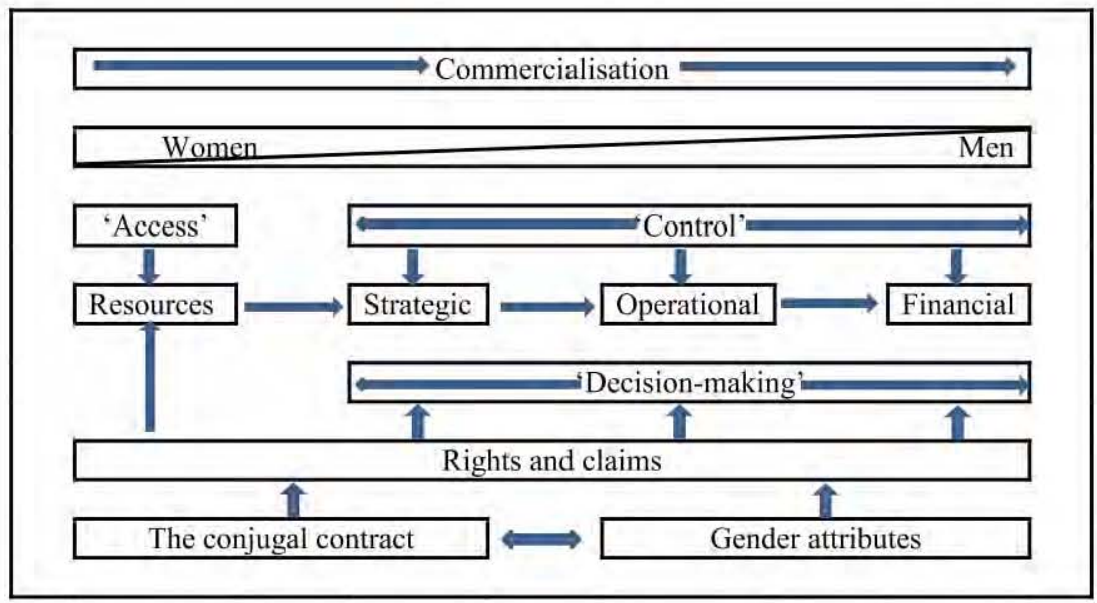

Figure 1. Conceptual framework for 'women's crops'

sale than home consumption (Geisler, 1993). Similarly, improved cowpea in northern Ghana became a 'man's crop' because it needed chemical sprays and knowledge of 'medicine' belonged to men (Padmanabhan, 2007). Hence, the commercialisation of 'women's crops' leads to disputes over meaning. The meaning of a word depends on how it is used in language. In turn, how language is used depends on who has the power to give words a specific meaning. As Chomsky (1979) argues, "questions of language are basically questions of power'. This view of language clearly influenced thinking on commercialisation in The Gambia. ${ }^{3}$ In the memorable words of Carney and Watts (1990), ultimate control over the income from a specific crop belongs to those who have 'the power to name'. The power to define a crop according to its gender attributes also gives the power to control the product. When they cease to be known as 'women's crops' that automatically belong to women, control becomes a matter for negotiation. The 'power to name' is therefore a litmus test for the impact of commercialisation on women.

The paper is divided into six sections. Section 2 outlines a conceptual framework, and Section 3 describes our data and methods. Section 4 explores verbal conflicts over 'the power to name' groundnuts as a women's crop, while the next section examine women's perceptions on the impact of mechanisation. The final section concludes.

\section{CONCEPTUAL FRAMEWORK}

Figure 1 provides a framework linking the main concepts used in the paper. Reading from top to bottom, we hypothesise that the commercialisation of 'women's crops' disempowers women because they can no longer enforce their claims to access and control.

We next distinguish between 'access' and 'control'. 'Access' has been defined as 'the ability to derive benefits from things' (Ribot \& Peluso, 2003), which equates access with effective control. However, 'access implies the right to use or benefit from a productive resource; control refers to the effective exercise of such rights' (Berry, 1989). In

\footnotetext{
${ }^{3}$ The title of Carney and Watts's (1990) article, Manufacturing Dissent, was a play on Herman and Chomsky's Manufacturing Consent (1988), which examined the influence of the media on public opinion.
} 


\section{A. Orr et al.}

Figure 1, we define access as the ability to use a given resource, without implying control over benefits or their use.

'Decision-making' is the term generally used by social scientists to operationalise 'control'. The standard practice is to identify key decision points, identify what role women play in making these decisions, which may then be combined into a single index (Alkire et al., 2013). We distinguish between three different types of control. As Doss (2001) points out, 'women's crops' should be defined not only by who controls the output but also by 'who chooses the crops to grow and who makes the management decisions'. We define 'strategic' control as the power to choose 'how' resources are allocated between competing crops, and 'operational' control as the power to choose 'what' and 'when' crop management operations are implemented. This is similar to Kabeer's (1999) distinction between 'policy-making' and 'management' control. Finally, we define 'financial' control as the power to choose 'who' receives the realised value or income from the crop. Figure 1 uses 'decision-making' to cover decisions about all three types of control—strategic, operational and financial.

'Rights and claims' are the mechanisms by which agents negotiate 'access' and 'control'. Ribot and Peluso (2003) define a right as 'an enforceable claim'. A 'right' is therefore a claim whose validity is recognised either by law, custom or popular opinion. In Africa, women's rights are complex because rights are divisible. Women may have rights over different uses of the same plant (Howard \& Nabanoga, 2007) or, as in the 'house property complex' in eastern Africa, rights to different categories of cattle (Oboler, 1996), or hold rights on behalf of others, such as rights in cattle for their sons (von Bulow, 1992).

'Rights' and 'claims' to control are mobilised in two ways. First, they are operationalised in the 'conjugal contract' that 'sets the terms by which husbands and wives exchange goods, income and services, including labour' (Whitehead, 1981). Like rights, the terms of conjugal contract are not fixed but are renegotiated in response to changing circumstances. Second, they are mobilised by the identification of specific 'gender attributes', which are culturally defined ways of classifying resources in terms of whether they share male or female traits. 'Women's crops', for instance, are defined by feminine attributes such as their importance for 'relish' or a balanced meal, and the responsibility of women to provide this part of the household diet then becomes part of the conjugal contract (Padmanabhan, 2007).

\section{DATA AND METHODS ${ }^{4}$}

Research was conducted in Eastern Province, Zambia, where groundnuts have historically been regarded as a 'women's crop'. Six in 10 farm households in this province grow groundnuts, which is second only to maize in terms of area planted, and one-fifth of the harvested crop is sold. Most groundnuts are sold to private traders. Processing is limited, and most are consumed as nuts (Mofya-Mukuka \& Shipekesa, 2013). Efforts are underway to commercialise groundnuts to supplement cotton, the traditional cash crop. The Eastern Province Farmers' Cooperative (EPFC), established in 2007, is a farmers' organisation that buys and sells groundnut seed. Shelling groundnuts is generally performed manually by women, but in 2012, EPFC distributed machine shellers to selected seed producer groups.

\footnotetext{
${ }^{4}$ For a full description of our methods, the tool and its applications, refer to Orr, Tsusaka, Homann Kee-Tui, and Msere (2014).
} 
The first shellers were distributed to the oldest and largest EPFC groups. Although the shellers are hand-operated and suitable for women, they are primarily operated by men. Scenting cash, men have begun to take an interest in groundnuts and to claim a greater role in decision-making for the crop, including a greater share of the income from sales.

\subsection{Measuring 'Control'}

To measure control, we developed a simple tool which we applied using a mixed method approach that combined qualitative and quantitative instruments. Testing hypotheses about social processes requires quantitative data (Gladwin et al., 2002). However, quantitative data on household decision-making are 'simple windows on complex realities' (Kabeer, 1999) that show the direction of control rather than exact measurements. As one female participant commented, decisions about control are 'bedroom decisions'- a private matter between husbands and wives. Qualitative data made those 'bedroom' decisions more visible.

Figure 2 shows the tool we developed to measure 'women's control'. The crops $\left(C_{1}-C_{4}\right)$ in each quadrant are the crops for which women's control is compared. The decisions $\left(D_{1}-D_{6}\right)$ are the key decisions for crop production and sale for which the degree of women's control is measured. The scores $\left(\mathrm{S}_{1}-\mathrm{S}_{6}\right)$ measure the degree of control that women have over these key decisions. Finally, the weights $\left(\mathrm{W}_{1}-\mathrm{W}_{6}\right)$ are the relative importance that women give to these key decisions $\left(D_{1}-D_{6}\right)$. The weighted scores are aggregated to produce a weighted gender control index (WGCI).

A sex-disaggregated WGCI was defined for each crop as follows: $W G C I_{\mathrm{g}}=\frac{\sum_{j=1}^{\mathrm{k}} W_{\mathrm{jg}} S_{\mathrm{jg}}}{\sum_{j=1}^{\mathrm{k}} w_{\mathrm{ig}}}$ where the subscript $j$ is a decision, $\mathrm{k}$ is the number of decisions and $\mathrm{g}$ refers to either male (husband) or female (main wife, which we defined as the oldest or first-married wife in a polygamous household).

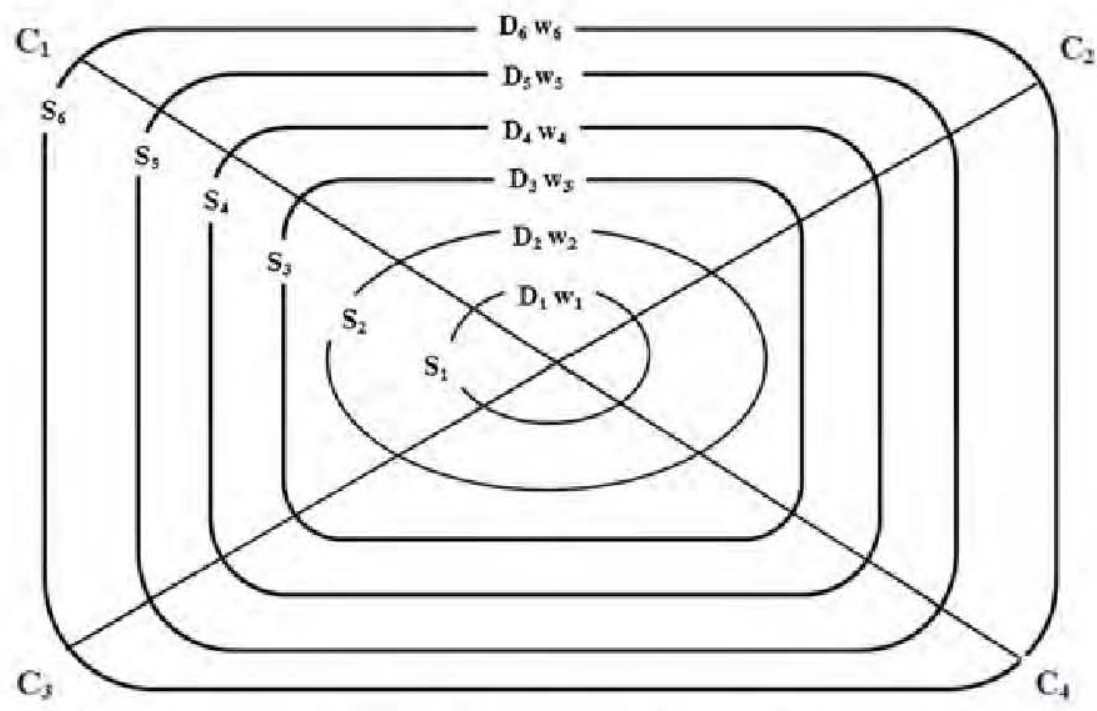

Figure 2. The 'Women's Crop Tool' 
Table 1. Socio-economic profile of group members

\begin{tabular}{lccccc}
\hline Variable & $\begin{array}{c}\text { Tercile 1 } \\
(n=96)\end{array}$ & $\begin{array}{c}\text { Tercile 2 } \\
(n=96)\end{array}$ & $\begin{array}{c}\text { Tercile 3 } \\
(n=95)\end{array}$ & $\begin{array}{c}\text { Mean } \\
(n=285)\end{array}$ & $(p$-value $)$ \\
\hline Production of groundnuts (kg, unshelled) & 136.3 & 423.0 & 1810.3 & 782.0 & 0.000 \\
Groundnuts sold (kg) & 87.4 & 270.5 & 1093.8 & 479.1 & 0.000 \\
Family size (no.) & 5.03 & 5.69 & 6.67 & 5.7 & 0.000 \\
Age of husband (years) & 36.2 & 39.3 & 40.8 & 38.4 & 0.075 \\
Age of main wife (years) & 30.3 & 33.6 & 34.7 & 32.5 & 0.052 \\
Education of husband (years) & 6.15 & 7.07 & 6.92 & 6.6 & 0.127 \\
Education of main wife (years) & 5.07 & 5.42 & 5.82 & 5.4 & 0.200 \\
Total area cultivated (ha) & 2.61 & 3.15 & 3.24 & 3.0 & 0.056 \\
Area planted to groundnuts (ha) & 0.37 & 0.65 & 0.89 & 0.6 & 0.000 \\
\hline
\end{tabular}

Source: Household Survey, 2014.

The tool was applied using focus group discussions (FGDs) where information was recorded on a wall chart, and a household survey, where the same information was collected using a structured questionnaire. In both cases, we asked how much 'control' women had over decision-making for groundnuts, cotton, maize and sunflower, and the relative importance of each decision. A full description of the questions and the questionnaire is given in Orr et al. (2014).

\subsection{Qualitative Data and Methods}

For qualitative data, we held FGDs with three types of EPFC seed producer groups, namely (i) groups with more than three years of experience of selling to EPFC, which we call 'commercial' groups; (ii) groups that had at least two years of experience with the machine sheller, which we call 'commercial sheller' groups; and (iii) groups that had recently joined EPFC, which we call 'non-commercial' groups. We purposively selected two villages that had EPFC seed producer groups in one of these categories, giving a total of six villages. ${ }^{5}$ We asked each group to select men and women to participate in FGDs. A total of 123 men and women participated in 12 FGDs (six with women and six with men), giving an average group size of 10 (Orr et al., 2014). All those who participated were members of EPFC seed-producer groups.

Table 1 shows a socio-economic profile of group members from the household survey (refer to succeeding texts), stratified according to their production of groundnuts. A survey for Eastern Province in 2010-2011 gives an average area of 0.47 planted to groundnuts and groundnut sales of $151 \mathrm{~kg}$ per household (IAPRI, 2014). Despite significant heterogeneity, the mean values for EPFC group members were 0.6 ha planted and $479 \mathrm{~kg}$ sold. This suggests that they were more commercialised than other groundnut growers.

The groups suggested four Chichewa words for control, including kulamulira ('being in charge'), kulongola ('lead or go before'), kudongosola ('arrange or speak in order') and ndondomekho ('following an agreed plan or procedure'). ${ }^{6}$ We ensured a common

\footnotetext{
${ }^{5}$ The villages were Kagunda and Mafuta (commercial+sheller), Bwanunkha and Kapenya (commercial) and Kazingizi and Stephen (noncommercial). All were located in Chipata district except for Bwanunkha, which was located in Chadisa district.

${ }^{6}$ For the English definitions of kulamulira and kulongola, refer to Guerin (1985), sv; for kudongosola, refer to Scott (1965), sv; and for ndondomekho, refer to Paas (2013), sv.
} 
understanding by using kulamulira as a reference point in all the FGDs. Each FGD scored how much control women had over each decision, using a percentage scale of $0-100$. The FGDs also scored the importance of each decision for overall control on a $0-5$ scale. We held separate FGDs with men and women. After each group had finished, they came together in a plenary session to share their results, and the discussion was recorded and translated.

\subsection{Quantitative Data and Methods}

A household survey was conducted with smallholder farmers in three purposively selected villages at least $15 \mathrm{~km}$ apart within the same agro-ecological zone. Kagunda (where we conducted FGDs) was the 'treatment' village that contained an EPFC seed producer group where a machine sheller had operated successfully for two crop seasons. The two 'control' villages without a machine sheller were Kapenya (where we conducted FGDs), and Mkhazika village in Katete district (where we did not conduct FGDs). Only households with both male and female adults were selected for interview. To elicit the gender division of control, we interviewed the husband and his main wife separately. The husbands and wives were interviewed by male and female enumerators respectively. Within each village, 100 households (i.e. 200 individuals) were randomly selected, giving a total of 100 households from the village with the machine sheller and 200 households from the two villages without a machine sheller.

To test hypotheses about women's control, we used univariate and bivariate analysis. Because both WGCI and the gender share of workload are indicators of perceived levels and the sum of men's and women's figures is generally not equal to 100, average indicators of control and workload can be defined by taking the average of men's and women's perceptions. That is, the average weighted gender control index (AWGCI) for women and men can be defined as:

$$
\begin{aligned}
& A W G C I_{\mathrm{f}}=\frac{1}{2}\left\{W G E I_{\mathrm{f}}+\left(100-W G C I_{\mathrm{m}}\right)\right\} \\
& A W G C I_{\mathrm{m}}=\frac{1}{2}\left\{W G E I_{\mathrm{m}}+\left(100-W G C I_{\mathrm{f}}\right)\right\}
\end{aligned}
$$

where $\mathbf{f}$ and $\mathrm{m}$ refer to female and male respectively. Likewise, the average gender share of workload can be defined as:

$$
\begin{aligned}
A G S W_{\mathrm{f}} & =\frac{1}{2}\left\{G S W_{\mathrm{f}}+\left(100-G S W_{\mathrm{m}}\right)\right\} \\
A G S W_{\mathrm{m}} & =\frac{1}{2}\left\{G S W_{\mathrm{m}}+\left(100-G S W_{\mathrm{f}}\right)\right\}
\end{aligned}
$$

Obviously, $A W G C I_{\mathrm{f}}+A W G C I_{\mathrm{m}}=A G S W_{\mathrm{f}}+A G S W_{\mathrm{m}}=100$ holds for each household. The deviation of these indicators from parity (i.e. 50) can be used to test the statistical significance of the gender gap in decision-making for control and workload.

To test the impact of the machine sheller on women's control, we used multivariate regression analysis. Because we have cross-section and observational data, and access to the machine sheller was not randomised, the results are open to sample selection bias. To reduce this bias, we used matching techniques. The key covariate is the area planted to groundnut, which is significantly greater in the sheller group $(p<0.000)$. 
Following Rosenbaum and Rubin (1983), we matched households according to their propensity score, predicted from observed covariates by logistic or probit regression, to create a counterfactual group. In view of the small sample size, our first choice of matching algorithm was nearest one-neighbour matching. Further details on methodology and testing of results may be found elsewhere (Orr et al., 2014). Finally, the following regression model was estimated by including the households from the sheller group and the matched households from the non-sheller groups:

$$
y_{\mathrm{i}}=\beta_{0}+\beta_{1} x_{\mathrm{i}}+\beta_{2} S_{\mathrm{i}}+\varepsilon_{\mathrm{i}}(\mathrm{i} \in \text { matched pairs })
$$

where $y$ is women's WGCI for groundnut, $x$ is a vector of covariates [groundnut area size, same religion (dummy), husband with an official position in the seed producer group (dummy), main wife with an official position in the seed producer group (dummy), polygamy (dummy), gender sum of age, gender gap in age, gender sum of groundnut farming years, gender gap in groundnut farming years, household headcount, household adult women ratio, the ratio of area planted to modern varieties for all crops], $S$ is the group dummy ( 1 for the sheller group, 0 otherwise), $\varepsilon$ is the random error term and i refers to the household. Groundnut production, sales and area planted are multicollinear and therefore cannot be included in the regression at the same time. Among the three, we opted for area planted because we judged this to be more reliable than self-reported figures for production and sales. Lastly, $\beta_{2}$ is designed to capture the average treatment effect on the treated to be estimated.

\section{4 'WOMEN'S CROPS' AND THE POWER TO NAME}

In this section, we compare women's perceived levels of control over groundnuts compared with other crops and compare differences in perceptions between women and men. We dissect the arguments used for and against groundnuts as a women's crop and show how the power to name reflected traditional views of gender roles and the conjugal contract.

We tested the hypothesis that groundnuts were a women's crop by comparing women's perceived control key decisions for groundnuts with cotton, maize and sunflower. The results show that the difference between cotton and groundnut was statistically highly significant for all eight decisions ( $p$-value for the paired $t$-test $<0.001$ ), supporting the conclusion that groundnuts were a women's crop.

Figure 3 compares the weighted scores for women's perceptions of control for the four crops. The left-hand panel presents the results from the FGDs, while the right-hand panel shows the results from the household survey. The women felt that they controlled all the major decisions about groundnuts from land preparation to the use of income but perceived that they had less control over cotton. Maize occupied the middle ground, with control shared fairly evenly between women and men. In terms of method, the women in FGDs perceived greater differences in control than the women interviewed in the household survey. The women saw groundnuts as firmly under their control. 'We make a bowl of peanut butter for the men and the children. The rest is for us. It's our money' (Kapenya). 'Men neglect groundnuts, but when it's time for marketing they start interfering.' (Kazingizi). 'Men come with a bleeding heart, not forcibly, but know that if they come humbly their wife will increase the amount of money from groundnuts she will give them' (Kazingizi). 

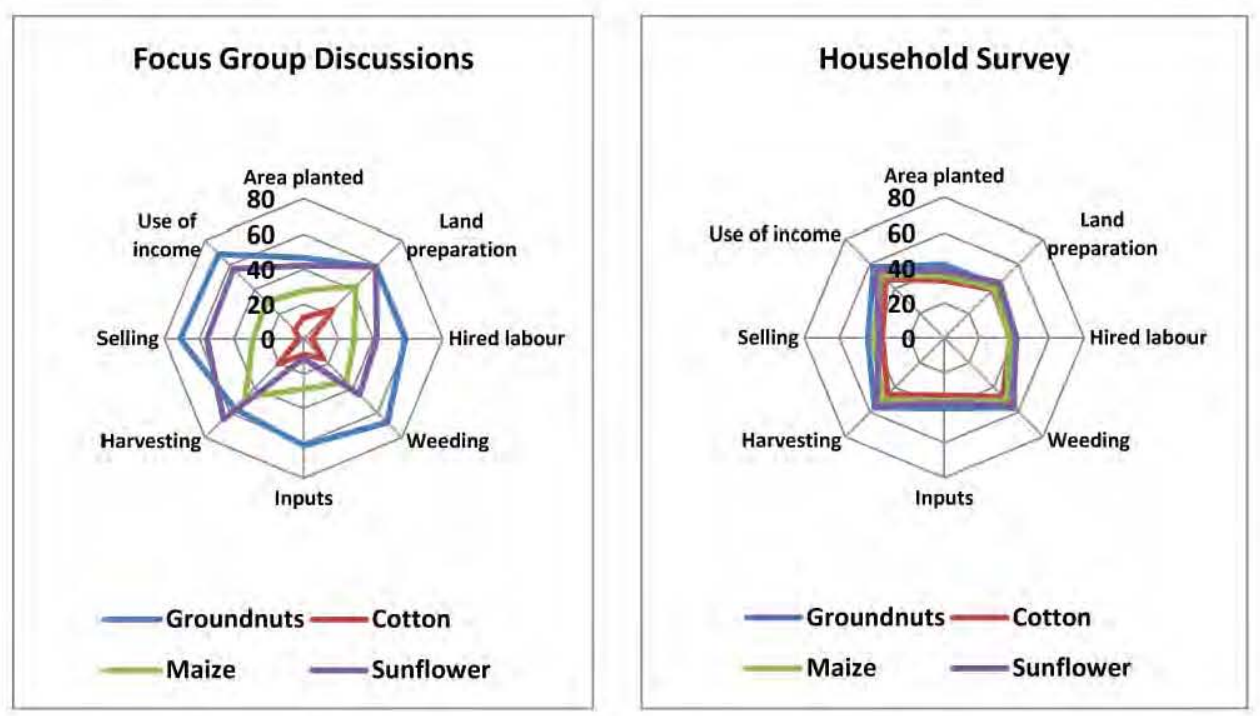

Source: Focus Group Discussions and Household Survey, 2014

Figure 3. Women's perceptions of control over groundnuts, cotton, maize and sunflower in Eastern Province, Zambia (weighted scores)

We tested the hypothesis that men and women disagreed over the level of women's control for groundnuts. The results confirmed that men and women differed sharply in their views on how much control women enjoyed over groundnuts, and that men saw themselves as exerting significant control over this 'women's crop'.

Figure 4 compares men's and women's perceptions of women's control for groundnuts and cotton. For groundnuts, the women perceived themselves as having more control (blue line), while the men perceived women as having less control (red line). For cotton, the opposite was true. The women perceived themselves as having very little control, whereas the men perceived women as having more control. In terms of method, both FGDs and the household survey gave similar results, but the women in the FGDs perceived that they had greater control over groundnuts and less control over cotton than did the women in the household survey. The different results between the FGDs and the household survey in Figures 3 and 4 may reflect smaller sample size and the public, confrontational nature of these discussions which may have polarised opinion and encouraged women to take a more extreme view of gender roles regarding these crops.

We asked the men and women how much control they perceived that women had over four crops and compared these perceptions using the paired $t$-test (Table 2). The test compared the difference between $A W G C I_{\mathrm{f}}$ and $100-A W G C I_{\mathrm{m}}$. The difference was statistically significant in all cases. In other words, the women believed that they had more control over decision-making for all four crops than the men thought they had.

The women based their 'right' to control groundnuts on two arguments. Firstly, the women asserted their moral right to control groundnuts because they provided most of the labour. 'If men want a few peanuts to eat, they will help, but that's all, they don't feel it's their job to weed groundnuts' (Kazingizi). 'Few men pay attention to the groundnuts field. When you work there, that's when your husband takes a bath and goes to drink beer' 

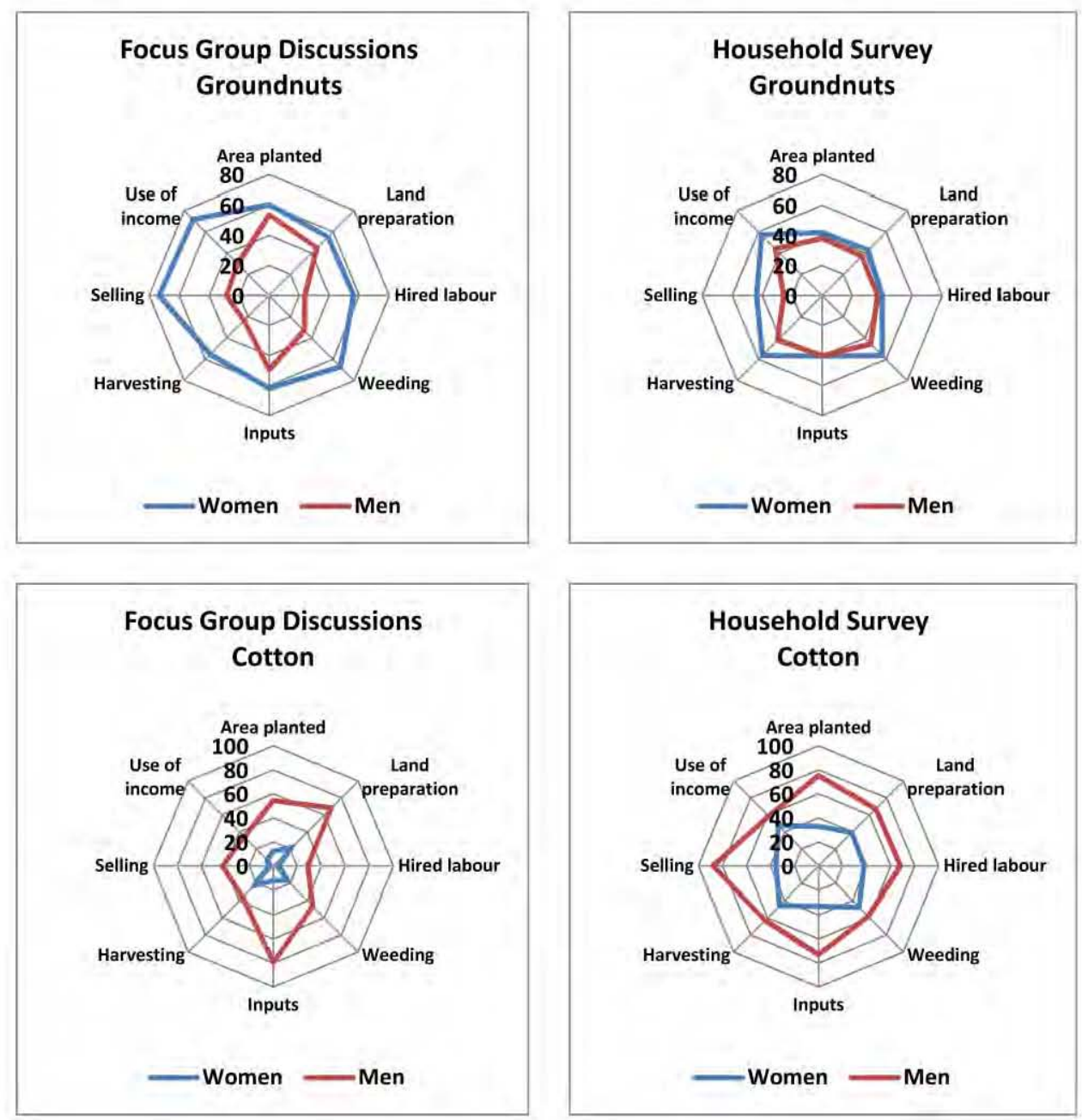

Source: Focus Group Discussions and Household Survey, 2014

Figure 4. Contrasting perceptions of women's control for groundnuts and cotton, by sex, Eastern Province, Zambia (weighted scores)

Table 2. Paired $t$-test on perceived difference in women's control

\begin{tabular}{lcccccc}
\hline \multicolumn{5}{c}{} & \multicolumn{4}{c}{ Women's control } \\
\cline { 3 - 5 } & $N$ & $\begin{array}{l}\text { Women's perception } \\
\left(A W G C I_{\mathrm{f}}\right)\end{array}$ & $\begin{array}{c}\text { Men's perception } \\
\left(A W G C I_{\mathrm{m}}\right)\end{array}$ & $\begin{array}{c}\text { Mean } \\
\text { difference }\end{array}$ & $t$-statistic & $p$-value \\
\hline Maize & 287 & 42.9 & 35.6 & 7.3 & 8.5 & 0.000 \\
Groundnut & 286 & 47.7 & 39.1 & 8.6 & 9.3 & 0.000 \\
Cotton & 206 & 39.4 & 34.1 & 5.3 & 6.2 & 0.000 \\
Sunflower & 183 & 45.0 & 43.1 & 1.9 & 2.9 & 0.004 \\
\hline
\end{tabular}

Source: Household Survey, 2014.

Note: The table compares the total level of control that men and women believe that women have over four crops. Higher values represent greater control. 
(Kapenya). 'Men won't even bother to step there' (Kapenya). 'My husband would rather weed cotton than groundnuts' (Kapenya).

To test if a higher workload gave the women greater control, we compared the correlation between the women's perceptions of their share of the workload $\left(G S W_{\mathrm{f}}\right)$ for maize and groundnuts with their perception of their degree of control over these crops, as measured by their total control $\left(W G C I_{\mathrm{f}}\right)$ and their control over the use of income. Workload was positively correlated with total control and control over use of income (Table 3). For the women, the correlation between their share of the workload and their control was statistically significant for both maize and groundnuts, suggesting that the women's workload did confer some degree of control. For the men, the correlation between workload and control was statistically significant for maize but not for groundnuts in either type of control. In the women's minds, therefore, their control over decisionmaking for groundnuts was associated with a greater share of the workload.

The women also based their 'right' to control groundnuts on the grounds of reciprocity because income from cotton was controlled by the men. 'No matter what you say, cotton is up to the men' (Kapenya). 'You can't even say anything about hired labour for cotton, it's a man's crop. That's the way marriages end' (Kazingizi). 'As for control of cotton sales, we can't even try' (Kapenya). 'They don't even tell you they've sold cotton. You count 10 bales then you see that two bales have gone, but they don't even mention anything about the money' (Kizingizi). 'Cotton gives ownership of money to go and drink beer and even marry another wife' (Kapenya). The women's role was simply to provide labour. 'You can work a few days on the groundnuts but the rest of the time you need to weed cotton. You can't even say anything' (Kazingizi).

We tested the hypothesis of reciprocity by comparing the correlation between the women's perception of their control over groundnuts and the men's control over maize and cotton (Table 4). The relationship is negative and statistically significant, implying that the higher the women's control over groundnuts, the higher their control over maize and cotton. The same applies to the men's perceptions. This suggests that there is no reciprocity between the women's control over groundnuts and the men's control over cotton. In short, the women with the most control over groundnuts had more control over cotton and not less.

One argument that the women did not use for their control of groundnuts was an appeal to tradition. In women-only FGDs, the women identified four attributes of 'women's

Table 3. Correlation between shares of workload and control in farming of maize and groundnuts

\begin{tabular}{lrrr}
\hline Gender & Control & Maize & \multicolumn{1}{c}{ Groundnuts } \\
\hline Women & Total control & $0.462^{1}$ & 0.278 \\
& & $p=0.000$ & $p=0.000$ \\
& Control over use of income & 0.222 & 0.269 \\
Men & Total control & $p=0.001$ & $p=0.000$ \\
& & 0.111 & 0.032 \\
& Control over use of income & $p=0.061$ & $p=0.596$ \\
& & 0.157 & 0.095 \\
& & $p=0.012$ & $p=0.116$ \\
\hline
\end{tabular}

Note: The table compares the correlation between women's perceived share of their workload for maize and groundnuts and their perceived share of total control over these crops, as perceived by women and men. A significant and positive correlation coefficient indicates that a higher workload is associated with higher control. ${ }^{1}$ Pearson's coefficient of correlation. 
Table 4. Correlation between women's control over groundnuts with men' control over maize and cotton

\begin{tabular}{lrr}
\hline & \multicolumn{2}{c}{ Women's control over groundnut versus } \\
\cline { 2 - 3 } & Men's control over maize & Men's control over cotton \\
\hline Women's perception & -0.760 & -0.587 \\
Men's perception & $p=0.000$ & $p=0.000$ \\
& -0.753 & -0.497 \\
& $p=0.000$ & $p=0.000$ \\
\hline
\end{tabular}

Note: A positive correlation indicates that higher control over groundnuts is associated with higher control over other crops. Higher values represent greater control.

${ }^{1}$ Pearson's coefficient of correlation.

crops': (i) there was no market (i.e. prices were low); (ii) the men contributed little labour; (iii) they were used as a relish, not the main meal; and (iv) they needed patience because they had to be shelled or picked from a pod. Conspicuously absent from this list is any mention of women's crops as a source of cash income. Rather, what distinguished women's crops was their low market value. Obviously, invoking tradition to justify the women's control over groundnuts was a dangerous argument because the recent rise in the price of groundnuts was precisely why the men had suddenly become interested in the crop.

For the men, the key argument against groundnuts as a women's crop was its emerging status as a cash crop. 'Groundnuts are not necessarily a women's crop, because it fetches a higher price than cotton. Groundnuts are not a women's crop. This house was built with money from groundnuts' (Men's FGD, Kagunda). 'We never used to consider groundnuts as a crop for men but now this is changing. It used to be a woman's crop. Now it's a crop for everyone' (men in plenary, Kagunda). The men therefore challenged the definition of groundnuts as a women's crop by invoking their traditional 'right' to control cash income. While the men stopped short of claiming groundnuts as a 'men's crop', based on the 'male' attribute of high market prices, they did claim that groundnuts was now gender-neutral, like maize. Renaming groundnuts as 'a crop for everyone' left open the thorny question of the 'power to name' and ultimate control.

Arguments over the power to name are based on a wider system of beliefs about gender roles. Among the matrilineal Chewa, crop agriculture was historically the concern of women because men were away for long periods occupied in hunting and trade (Morris, 1988). Although in our survey area, inheritance was no longer matrilineal, the older culture was reflected in traditional beliefs about gender roles. Women were responsible for the daily meal and for the relish crops. Responsibility for maize, the staple food crop, was shared between men and women. Men were responsible for providing cash for essential items and for buying maize when it ran out. ${ }^{7}$ In the settler economies of eastern Africa where the colonial state limited the export crops that Africans could grow, the main source of cash income was wage employment. In Zambia, therefore, the association of cash income with men goes back to the colonial period, when the imposition of hut tax forced

\footnotetext{
${ }^{7}$ Our main source for traditional gender roles and responsibilities in the survey area is the 1977 study of Kefa village (Skjonsberg, 1989, pp. 37-38, 83, 88). Kefa is located $30 \mathrm{~km}$ from Chipata town, compared with an average of $50 \mathrm{~km}$ for our survey villages. For similar traditions in other parts of Zambia, refer to Geisler (1993) for the southern region and Crehan (1983) for the north-west. We use the label 'traditional' in a restrictive sense because precolonial views of gender roles may have been very different (von Bulow, 1992).
} 
men to supply labour for white-owned farms and mines (Pletcher, 1979). The economic imperatives of colonialism made cash a male domain.

The women in FGDs echoed these traditional beliefs. 'Groundnuts are a food, so we control food for the household' (Kapenya). 'Maize is a critical crop. If a man decides not to keep some bags to eat, it's his responsibility to find piece-work to earn cash to buy maize' (Kapenya). 'When we need income quickly, we decide to use the sheller. The man is responsible for bringing in cash income' (men's FGD, Kagunda). 'Men have to make sure there's money in the house. That's why they're interested in groundnuts' (Kazingizi). Hence, the conjugal contract acts as a reference point both for women defending their right to groundnuts and for men staking claims to the cash from groundnut sales.

Commercialisation threatens the conjugal contract because it reverses traditional gender roles. The women now find themselves growing a cash crop that rivals cotton. The power to name serves to preserve the conjugal contract by rethinking the status of groundnuts as a 'women's crop'. Deeply rooted beliefs over gender roles help explain why 'women's crops' aroused such strong emotions in FGDs. The men's motivation was not simply financial-the selfish wish to boost income-but cultural. Naming groundnuts as a 'woman's crop' reflects a cultural definition of gender in which cash for household needs is provided by men. The commercialisation of women's crops challenges this definition by putting cash into the hands of women. From a male perspective, women who insisted that groundnuts should remain a 'woman's crop' were usurping male identity. ${ }^{8}$ An economistic view that sees gender conflicts in purely material terms misses this cultural dimension.

\section{COMMERCIALISATION AND CONTROL}

In this section, we test the hypothesis that commercialisation has reduced women's control over groundnuts and assess how women view men's participation in groundnuts. The results suggest the need to rethink the view of commercialisation and gender as a zero sum game.

We tested the hypothesis that the introduction of the machine sheller for groundnuts, which is operated primarily by men, would reduce women's perceived level of control over groundnuts. The results showed that the women perceived that the sheller had actually increased their control over groundnuts, leading us to reject the hypothesis that mechanisation had reduced women's control.

Table 5 shows the results of the matched regression using the selected matching algorithm. The women's $W G C I_{\mathrm{f}}$ is positively related to a membership of a sheller group, and the coefficient is statistically significant at the five per cent level. Other covariates also significantly affect women's control. Women in polygamous households had greater control over groundnuts, which is consistent with previous research showing that Zambian women in a polygamous marriage enjoy greater autonomy (Crehan, 1983). Adoption of improved groundnut seed also had a negative effect on women' control, perhaps because in such households, men were more actively involved in making farming decisions.

\footnotetext{
${ }^{8}$ This sometimes worked to women's advantage. Women in Malawi resisted attempts by the colonial state to make them sell groundnuts for cash in order to pay hut tax because this was a male responsibility. They continued to sell groundnuts to Indian traders, but for cloth (Bezner-Kerr, 2010).
} 
Table 5. Result of matching regression

Dependent variable: Women's Gender Control Index $\left(W G C I_{\mathrm{f}}\right)$ for groundnuts

Treatment variable: sheller group (yes $=1$ )

\begin{tabular}{|c|c|c|c|c|}
\hline $\begin{array}{l}\text { Matched } \\
\text { regression }\end{array}$ & Variable & Coefficient & $t$-statistic & $p$-value \\
\hline \multirow{14}{*}{$\begin{array}{l}F(13,158)=2.58 \\
p \text {-value }=0.003 \\
R^{2}=0.175\end{array}$} & Sheller group (yes = 1) & 6.56 & 3.17 & 0.002 \\
\hline & Area planted to groundnuts & 1.82 & 1.37 & 0.172 \\
\hline & Spouses of same religion (yes $=1$ ) & 0.88 & 0.41 & 0.681 \\
\hline & $\begin{array}{l}\text { Husband has official position in EPFC group } \\
(\text { yes = 1) }\end{array}$ & -2.00 & -0.53 & 0.594 \\
\hline & $\begin{array}{l}\text { Wife has official position in EPFC group } \\
(y=s=1)\end{array}$ & 1.80 & 0.48 & 0.632 \\
\hline & Polygamy $($ yes $=1)$ & 10.71 & 2.31 & 0.022 \\
\hline & Sum of age & 0.11 & 2.00 & 0.047 \\
\hline & Gap in age (age of husband - age of wife) & -0.37 & -1.79 & 0.076 \\
\hline & Sum of experience with groundnuts & -0.11 & -1.42 & 0.157 \\
\hline & $\begin{array}{l}\text { Gap in experience with groundnuts (experience } \\
\text { of husband - experience of wife) }\end{array}$ & 0.09 & 0.28 & 0.782 \\
\hline & Household size & -0.37 & -0.74 & 0.462 \\
\hline & Household adult female ratio & -31.60 & -1.71 & 0.089 \\
\hline & Area planted to improved seed, all crops (\%) & -8.57 & -2.16 & 0.033 \\
\hline & Constant & 59.69 & 5.68 & 0.000 \\
\hline
\end{tabular}

Although the area planted to groundnuts was a key determinant of receipt of treatment (i.e. provision of machine shellers), its effect on women's control is not statistically significant. Moreover, replacing the area planted to groundnuts with the volume of groundnuts sold also gave an insignificant coefficient $(p=0.307)$. Because neither the area planted to groundnuts nor the amount of groundnuts sold was negative or statistically significant, this suggests that the commercialisation of groundnuts did not reduce women's control.

A closer examination showed differences in the type of control exercised by the women in EPFC groups with and without the machine sheller. The women with access to a machine sheller perceived that they had greater control over land preparation $(p=0.0976)$, weeding $(p=0.0167)$, harvesting $(p=0.0016)$ and the use of income $(p=0.0296)$ from groundnuts (Orr et al., 2014). Thus, post-harvest mechanisation increased the women's operational and financial control, but the men retained strategic control over the area planted to groundnuts.

Why did the women not associate male participation in shelling with a loss of control? Machine shelling significantly reduced women's workload. ' 'Women will shell one bag a day then stop and do household chores, but men can spend the whole day shelling 20 bags. When it was shelled by hand, men had no control' (Kagunda). However, the women had no objection to sharing control for shelling. 'Women decide to use the groundnut sheller because they know that men will not help shell by hand. While women cook, men can be

\footnotetext{
${ }^{9}$ The machine sheller used by EPFC seed producer groups is operated by three people and can shell four $50 \mathrm{~kg}$ bags in $1 \mathrm{~h}$ or thirty-two $50 \mathrm{~kg}$ bags in a working day of $8 \mathrm{~h}$, averaging $533 \mathrm{~kg}$ per person. In one eight-hour day, a woman can shell $25 \mathrm{~kg}$ by hand. Thus, a machine sheller can do the work of 20 women in one day. Farm Management data from Eastern Province in the 1970s show that it required $2426 \mathrm{~h} \mathrm{ha}^{-1}$ to cultivate groundnuts, of which $950 \mathrm{~h}$ (39 per cent) was spent on shelling (Skjonsberg, 1989, p. 46 note 9).
} 
busy doing the shelling' (Kagunda). Furthermore, the men now searched for improved seed, checked if groundnuts were ready for harvesting and provided a bicycle or ox-cart to take groundnuts to market.

The women were therefore engaged in a difficult balancing act: keeping their 'right' to control over groundnuts while reducing their own workload by using men's labour for shelling, which in turn exposed them to male 'claims' for greater control. But the women were in no doubt that they had the best of the bargain. 'Men now do shelling. They never used to do that. Men never used to help us but now they know there's money, they have joined us, so we are very happy' (Kazingizi). Thus, the women saw reduced control over shelling less as losing control over groundnuts but more as liberating them from drudgery and as an opportunity to increase income for the household as a whole.

The women recognised that without greater male involvement, their households would not reap the full benefits of commercialisation. 'We thank men for coming in to help growing groundnuts, we can go higher and higher' (plenary, Kazingizi). They did not challenge men's strategic control over land but argued that giving women more land to plant groundnuts would benefit the whole household. 'We don't come with land but if we have control of land other decisions will be easier to make' (Kazingizi). 'You cannot talk of cash income from groundnuts if you don't have control over land' (Kazingizi). Higher prices for groundnuts had made men more receptive to these arguments. 'Groundnuts are now the main cash crop. Husbands have to decide with their wives how to use the income from groundnuts. The decision has to be made jointly. Men deciding alone would mean the end of the marriage' (men's FGD, Kagunda). The women rationalised this willingness to share control by an ideology of altruism, seeing it as the price they must pay to bring greater benefits for the family. Nevertheless, the idiom they used was still one of men 'helping' women rather than being treated as equal partners.

Why did the women perceive commercialisation as increasing their control over groundnuts while then being willing to reduce their control by sharing it with men? We believe that this paradox can be explained by the way the research question was framed. The tool we developed (Figure 2) was based on the assumption that commercialisation was a zero sum game. It saw control as a finite category and asked women how much control they had compared with men. On the other hand, it did not ask how much control women would be willing to share with men in exchange for higher income from groundnuts. This research question requires a different frame of reference based on cooperation rather than conflict and focusing on mutual advantage rather than autonomous control. The narrowness of our original research question became apparent only when we started listening to what women were saying. Our preconceived framework left no room for cooperation to achieve a common goal, which emerged spontaneously during the plenary sessions of the FGDs.

The expressed willingness of women to share control as a means to increase aggregate household income suggests that we are missing something important, namely that households are characterised by 'the co-existence of extensive conflicts and pervasive cooperation' (Sen, 1990, emphasis added). A 'cooperative-conflict' model of the household that envisages commercialisation as more than a zero sum game may be a more appropriate framework for understanding how the commercialisation of women's crops affects women. True, women in The Gambia and Cameroon lost control over irrigated rice, but they used their bargaining power to extract wages for work on family-owned fields, which left them better off than before (von Braun \& Webb, 1989; Jones, 1986). Similarly, an analysis of the introduction of new technology for rain-fed agriculture in the Sahel 


\section{A. Orr et al.}

showed that, compared with other models, the 'cooperation-conflict' model of the household gave the highest increase in total household income, and that women were financially better-off being paid to work on communal fields, which were more productive, than on their own less productive plots (Sanders et al., 1996). In other words, women gained by trading control for higher income.

Women's bargaining power rests primarily on their labour power. 'If a man just keeps and spends his money, women will not cultivate his [cotton] field next season' (Bwanunkha). 'If my wife doesn't agree, we cannot grow cotton' (Kagunda). In Uganda, bargaining proved an effective way for women to retain control as their crops were commercialised (Sorenson, 1996). On the other hand, women's bargaining power is weakened by the consequences of divorce if they insist on retaining full control (Dolan, 2001; Lim et al., 2007). Disputes over the meaning of 'women's crops' may therefore be determined by mutual interest rather than by outright victory for one side. As happened with women's vegetable gardens in The Gambia, what starts as a war of words over 'the power to name' can end in a compromise that leaves women with a significant degree of control (Schroeder, 1996).

This suggests the need for new research questions. How much autonomy are women groundnut growers in Zambia women willing to trade in order to increase overall household income? Do women really have a choice? How much control would satisfy men if overall income increased? What bargain would satisfy both parties? Why does bargaining apparently work in some contexts but not in others? Future research using behavioural economics offers new and exciting possibilities to answer these questions and help evaluate the benefits as well as the costs of commercialisation for women.

\section{CONCLUSION}

Our results confirmed that in Zambia's Eastern Province, groundnuts were a women's crop. Women saw themselves as having significantly greater control over groundnuts than over cotton, which they perceived as a man's crop. However, men and women differed in their views on women's degree of control. Women saw men as having a lower level of control over groundnuts, while men saw their level of control as higher than that perceived by women. Similarly, women saw men as having a higher level of control over cotton, while men saw the level of women's control as higher than that perceived by women. Despite these differences, the results are clear evidence that men and women recognised a gender division of control for groundnuts and cotton.

The commercialisation of groundnuts has sparked debate over its status as a women's crop. The women based their claim to name groundnuts as a women's crop on their greater share of the workload and men's monopoly over income from cotton. The men contested this by invoking a traditional view of gender roles where men provide cash income while women provide the daily meal. Cash income from women's crops was seen as subverting this moral order which formed the basis of the conjugal contract. Decisions about the allocation of resources and about how the benefits of commercialisation were shared were therefore played out as disputes over meaning and the power to name.

Contrary to expectation, we found that women did not perceive that mechanised shelling, increasing the area planted to groundnuts, or higher groundnut sales reduced their level of control over groundnuts. Indeed, women belonging to groups with a machine sheller reported higher levels of control over key decisions, including control over the 
use of income. The women in FGDs welcomed men's participation in machine shelling, which reduced their drudgery in hand shelling. The women also seemed willing to surrender some degree of control over groundnuts in exchange for greater help from men.

The dominant narrative sees commercialisation as a zero sum game in which men and women struggle for autonomous control. This is only part of the story. Women groundnut growers in Zambia also saw commercialisation as an opportunity for greater cooperation that could benefit the household as a whole. This suggests that a 'cooperative-conflict' model of the household may hold greater explanatory power for understanding how commercialisation might affect women than a conflict model based solely on capturing changes in autonomy and control. The scope for conflict and cooperation depends on the specific historical context and variations in women's bargaining power. Which will prevail is an empirical question. In the present case, commercialisation looks certain to change the status of groundnuts as a women's crop, reducing women's operational and financial control, but women may consider this a price worth paying if they can negotiate shared control over a bigger cash income.

\section{REFERENCES}

Alkire S, Meinzen-Dick R, Peterman A, Seymour G, Vaz A. 2013. The Women's Empowerment in Agriculture Index. World Development 52: 71-91.

Berry S. 1989. Access, control and use of resources in African agriculture: an introduction. Africa $\mathbf{5 9}$ (1): $1-5$.

Bezner-Kerr R. 2010. Groundnuts as 'economic crop' or 'wife of the home' in Northern Nyasaland. Journal of Historical Geography 36: 79-89.

Boserup E. 1989. Woman's Role in Economic Development. Earthscan Publications Limited: London.

Bryceson DF. 1995. African women hoe cultivators: speculative origins and current enigmas. In Women Wielding the Hoe: Lessons from Rural Africa for Feminist Theory and Development Practice, Bryceson DF (ed). Berg: Oxford and Washington, DC; 3-22.

Carney J. 1988. Struggles over crop rights and labour within contract farming households in a Gambian irrigated rice project. Journal of Peasant Studies 15(3): 334-349.

Carney J. 1992. Peasant women and economic transformation in The Gambia. Development and Change 23(2): 67-90.

Carney J. 1998. Women's land rights in Gambia irrigated rice schemes: constraints and opportunities. Agriculture and Human Values 15: 325-336.

Carney J, Watts M. 1990. Manufacturing dissent: work, gender and the politics of meaning in a peasant society. Africa 60(2): 207-241.

Carney J, Watts M. 1991. Disciplining Women? Rice, mechanization, and the evolution of Mandinka gender eelations. Signs 16(4): 651-681.

Carr EH. 2008. Men's crops and women's crops: the importance of gender to the understanding of agricultural and development outcomes in Ghana's central region. World Development 36(5): 900-915.

Chomsky N. 1979. Language and Responsibility. Harvester Press: Brighton.

Cloud K. 1985. Women's productivity in agricultural systems: considerations for project design. In Gender Roles in Development Projects: A Case Book, Overholt C, Anderson M, Cloud K, Austin JE (eds). Kumarian Press: West Hartford, Connecticut; 17-55. 
Crehan K. 1983. Women and development in north western Zambia: from producer to housewife. Review of African Political Economy 27/28: 51-66.

Dey J. 1981. Gambian women: unequal partners in rice development projects? Journal of Development Studies 17(3): 109-122.

Dey J. 1982. Development planning in The Gambia: the gap between planners' and farmers' perceptions, expectations and objectives. World Development 10(5): 377-396.

Dolan CS. 2001. The good wife: struggles over resources in the Kenyan horticultural sector. Journal of Development Studies 37(3): 39-70.

Doss CR. 2001. Designing agricultural technology for Africa women farmers: lessons from 25 years of experience. World Development 29(12): 2075-2092.

Doss CR. 2002. Men's crops? Women's crops? The gender patterns of cropping in Ghana. World Development 30(11): 1987-2000.

Enete A, Nweke F, Tollens E. 2002. Contribution of men and women to food crop production labour in Africa: information from COSCA. Outlook on Agriculture 31(4): 259-265.

Guerin J. 1985. A Concise English-Chichewa Dictionary. A Draft from Personal Notes, 2. Blantyre: Malawi: typescript.

Geisler G. 1993. Silences speak louder than claims: gender, household, and agricultural development in southern Africa. World Development 21(12): 1965-1980.

Gladwin CH, Peterson JS, Mwale AC. 2002. The quality of science in participatory research: a case study from eastern Zambia. World Development 30(4): 523-543.

Herman ES, Chomsky N. 1988. Manufacturing Consent: The Political Economy of the Mass Media. Pantheon Books: New York.

Howard PL, Nabanoga G. 2007. Are there customary rights to plants? An inquiry among the Baganda (Uganda) with special attention to gender. World Development 35(9): 1542-1563.

Jones CW. 1986. Intra-household bargaining in response to the introduction of new crops: a case study from Northern Cameroon. In Understanding Africa's Rural Household and Farming Systems, Moock J (ed). Westview Press: Boulder; 105-123.

Indaba Agricultural Policy Research Institute (IAPRI), 2014. Unpublished data from Rural Livelihoods Survey 2010-11.

Kabeer N. 1999. Resources, agency, achievements: reflections on the measurement of women's empowerment. Development and Change 30: 435-463.

Lim SS, Winter-Nelson A, Arends-Kuenning A. 2007. Household bargaining power and agricultural supply response: evidence from Ethiopia coffee growers. World Development 35(7): 1204-1220.

Mofya-Mukuka R, Shipekesa A. 2013. Value Chain Analysis of the Groundnuts Sector of the Eastern Province of ZambiaWorking Paper No. 78.. Indaba Agricultural Policy Research Institute. Mimeo: Lusaka; 41.

Morris B. 1988. The Power of Animals. An Ethnography. Berg: London.

Oboler RS. 1996. Whose cows are they anyway?: ideology and behaviour in Nandi cattle "ownership" and control. Human Ecology 24(2): 255-272.

Orr A, Tsusaka TW, Homann Kee-Tui S, Msere H. 2014. What do we mean by 'women's crops'? A mixed methods approach. ICRISAT SocioEconomics Discussion Paper Series No. 23. Mimeo, 42 pp. http://oar.icrisat.org/8331/1/ISEDPS_23_2014.pdf (Accessed on 24 March 2016).

Paas S. 2013. Dictionary. Mthauthanziramawu. English/Chichewa/Chinyanja, 4th edition. Christian Literature Action in Malawi (CLAIM): Nanjing.

Padmanabhan MA. 2007. The making and unmaking of gendered crops in northern Ghana. Singapore Journal of Tropical Geography 28: 57-70.

Pletcher, J. 1979. Agricultural Change in Eastern Province, Zambia. Paper presented at the African Studies Association Conference, 31 Oct - 3 Nov 1979, Los Angeles, USA. Mimeo, 32 pp. 
Ribot JC, Peluso NL. 2003. A theory of access. Rural Sociology 68(2): 153-181.

Rosenbaum PR, Rubin DB. 1983. The central role of the propensity score in observational studies for causal effects. Biometrica 70(1): 41-55.

Sanders JH, Shapiro BI, Ramaswamy S. 1996. The Economics of Agricultural Technology in Semiarid Sub-Saharan Africa. The Johns Hopkins University Press: Baltimore.

Schroeder RA. 1996. "Gone to their second husbands": marital metaphors and conjugal contracts in the Gambia's female garden sector. Canadian Journal of African Studies 30(1): 69-87.

Scott, DC. 1965. Dictionary of the Nyanja Language, edited and enlarged by A. Hetherwick. Lutterworth Press, London, United Society for Christian Literature.

Sen A. 1990. Gender and cooperative conflicts. In Inequalities, Women and World Development, Tinker I (ed). Oxford University Press: Oxford; 123-149.

Skjonsberg E. 1989. Change in an African Village: Kefa Speaks. Kumarian Press: West Hartford, Connecticut.

Sorenson P. 1996. Commercialisation of food crops in Busoga, Uganda and the renegotiation of gender. Gender and Society 10(5): 608-628.

von Braun J, Webb JR. 1989. The impact of new crop technology on the agricultural division of labor in a West African setting. Economic Development and Cultural Change 37(3): 513-534.

von Bulow D. 1992. Bigger than men? Gender relations and their changing meaning in Kipsigis society, Kenya. Africa 62(4): 523-546.

Whitehead A. 1981. 'I'm hungry, mum': the politics of domestic budgeting. In Of Marriage and the Market: Women's Subordination in International Perspective, Young K, Wolkowitz C, McCullagh R (eds). CSE Books: London; 88-111.

World Bank, 2015. Agriculture in Africa: Telling Facts from Myths. http://www.worldbank.org/en/ programs/africa-myths-and-facts (Accessed on 24 March 2016). 